\title{
Managing Salinity in Tunisian Oases
}

\author{
Mohamed Hachicha ${ }^{1}$ and Imed Ben Aissa ${ }^{2}$ \\ 1. Laboratory of Valorization of non Conventional Water, National Institute of Rural Engineering, Waters and Forest, Ariana 2080 , \\ 17 Rue Hédi Karray, Tunisia
}

2. Regional Research Centre of Horticulture and Biological Agriculture, Chott Meriem BP 57-4042, Sousse, Tunisia

Received: June 03, 2014 / Accepted: September 03, 2014 / Published: September 30, 2014.

\begin{abstract}
The Tunisian oases face serious problems of waterlogging and salinization caused by mismanagement of water and soil resources and the reduced discharge of drainage water. The oases space is based on a fragile balance between water, soil and man, which is now changed by modern irrigation and drainage systems. The oases pump most of their water from deep aquifers and only to a small degree from shallow aquifers. The quality of the irrigation water and the presence of a shallow saline water table are the main causes of salinization of the oases. Concerning the salt-affected landscapes and hydro-saline dynamic, the authors distinguish an equilibrium dynamic of salts to the parcel which depends on water management, and an equilibrium dynamic at the level of the basin watershed which is powered by drilling and ending in hypersaline depressions. For the management of salinization and waterlogging, a combination of agricultural management techniques are used, the first being modern methods of irrigation and drainage. Other, less used methods are sandy amendment, the reuse of drainage waters, geothermal waters and of treated wastewater.
\end{abstract}

Key words: Water, irrigation, drainage, salinity, oases, Tunisia.

\section{Introduction}

The Tunisian oases constitute less than $10 \%$ of the irrigated areas (about 400,000 ha), but they are the most important agricultural and socio-economic activity of the desert region. Agricultural production in these areas is also important for Tunisia. The oases are affected by an increasing water table and salinization caused by the mismanagement of water and soil resources and the insufficient drainage of water [1, 2]. Although water resources are limited and often not renewable, the water use efficiency is often low. The oases space is based on a fragile balance between water, soil and man. The Tunisian oases are classified in different types: coastal oasis, continental oasis and mountain oasis with a subdivision in traditional oasis and recent creations. All oases are affected by the modernization of

Corresponding author: Mohamed Hachicha, Ph.D., senior researcher, research field: soil sciences. E-mail: hachicha8@gmail.com. irrigation and drainage systems. The oases draw most of their water from deep and very little from shallow aquifers:

- The water of the Intercalary Continental (CI) is characterized by a high temperature $\left(50-70{ }^{\circ} \mathrm{C}\right)$ and salinity ranging from 2 to $6 \mathrm{~g} / \mathrm{L}$. It is pumped from depths between 1,000 and $2,000 \mathrm{~m}$. It is more and more exploited.

- The water of the Terminal Complex (CT) has cold waters. It is pumped from depths between 40 and $300 \mathrm{~m}$ and has a moderate to high saline water (2 to 8 $\mathrm{g} / \mathrm{L})$. It provides most of the water used for agriculture. This aquifer is overexploited.

- The saline (2.6-3.5 g/L) Jeffara aquifer is found in the coastal oases of Gabes.

- The oases aquifers: because they lie only a few meters below the surface, they are first used by wells. These aquifers have salinity between $3 \mathrm{~g} / \mathrm{L}$ and $18 \mathrm{~g} / \mathrm{L}$. They are fed by seepage from rain, irrigation or drainage, as well as underground lateral fluxes from groundwater of the Dahar Mountain. 


\section{Salinization and Waterlogging Problems}

\subsection{Spatial Extent of Salinization and Waterlogging}

The quality of the irrigation water and the presence of a shallow saline water table are the main causes of salinization of the oases. Of a total area of about 48,000 ha, about $50 \%$ are irrigated by water with more than $3 \mathrm{~g}$ salts/L (Table 1) and about one third is affected by a shallow and saline water table.

\subsection{Salt-affected Landscapes and Hydro-saline Dynamic}

The oases have been created originally around natural springs on sandy, clay and gypsum soils. The Oases landscape is composed of an upstream part of shallow Aeolian sandy soils with a gypsum crust and a downstream part of deeper Aeolian sandy soils with younger gypsum crusts caused by high water tables. Soils become affected by waterlogging in the Chotts (Form of big sebkha). The spatial distribution of soil types is based on topography which determines the water level and the transfer of salt. These soils can contain consolidated gypsum fossil formations in deeper layers. Irrigation also transforms the gypsum in the sandy wind material to crusts near the watertable that prevent the infiltration of water [3]. Distinguish equilibrium of salinization at the parcel which depends on water management and equilibrium at the watershed level which is caused by drilling and which ends in hypersaline depressions. The extension of an oasis occurs in low-lying areas where water is available. This progression is stopped by a hypersaline and waterlogging depression composed of fine alluvium (Sebkha or Chott). The dynamics of the salts in the oasis show a typical pattern: From upstream to downstream, the salt concentration of the water increases until it precipitates downstream.

In well irrigated parcels, salinity is increasing with depth. The electrical conductivity of the aqueous extract of saturated paste soil (ECe) is lower in the surface layer than in the deep layers. In poorly drained and poorly irrigated low-lying areas, profiles are decreasing. The ECe is higher in the surface layer than in the deep layer. When an oasis is affected by a water deficit, salinization becomes more evident. Generally, the salinity in surface layers is about $5 \mathrm{dS} / \mathrm{m}$ which seems to be close to salt equilibrium of a gypsum soil. Salinization and waterlogging problems appear generally about 5 years after the beginning of irrigation when a relative equilibrium salt regime is established. Thus, the oasis of Regime Maatoug experienced a significant increase in the water table level after five years of first irrigation causing salinization of the soil and a decrease of the yield of palm trees.

\subsection{Regional Trends}

\subsubsection{The Coastal Oases of Gabes}

The oases of the El Hamma and Zerkine group are more affected by salinity than Gabes North and Mareth oases. The oases of Gabès are situated around perennial sources. In the 1970s, the outflow has decreased and some sources have dried up. The soils of some neglected oases have become very saline with more than $15 \mathrm{dS} / \mathrm{m}$ at El Hamma. In 1980s, the oasis of El Aouinet (near Methouia) was abandoned because of extremely high salinity. To cope with this situation, the project of rehabilitation of the oasis of Gabes has implemented a new drilling and appropriate hydraulic system [4]. In general, the soil salinity increases

Table 1 Estimated area of vulnerable oases to salinity.

\begin{tabular}{|c|c|c|c|c|c|}
\hline \multirow{2}{*}{ Governorate } & \multirow{2}{*}{ Area (ha) } & \multicolumn{2}{|c|}{ Irrigated area $(>3 \mathrm{~g} / \mathrm{L})$} & \multicolumn{2}{|c|}{ Water table depth (about 1-2 m) } \\
\hline & & $\mathrm{Ha}$ & $\%$ & $\mathrm{Ha}$ & $\%$ \\
\hline Gafsa & 14361 & 2123 & 15 & 90 & $<1$ \\
\hline Tozeur & 8024 & 5192 & 65 & 1329 & 17 \\
\hline Gabes & 10009 & 6613 & 66 & 3433 & 34 \\
\hline Kebili & 15604 & 8536 & 55 & 9120 & 58 \\
\hline Total & 47998 & 22464 & 47 & 13972 & 29 \\
\hline
\end{tabular}


considerably in the less irrigated sectors and on abandoned parcels due to capillary rise. The absence of external drainage results in an increasing water table especially in parcels near the depression. Several hydropedologic, agro-climatic and anthropogenic factors, contribute to the emergence of a more or less intense salinization in the different sectors of the oasis. Most are closely related to the deterioration of soil and water management. The reclamation of salt-affected soil in the oasis of Gabes is feasible but only if the water table is kept at a minimum depth of to $1 \mathrm{~m}$.

\subsubsection{The Continental Oases of Gafsa}

The ancient oases of Gafsa suffer from a fragmentation of the farms. Gafsa South-West oasis is cultivated since Roman times. Without any change in the management of water and soil, the evolution of the soil salinity is very slow. The monitoring of the soil salinity carried out in 1966 and 1989 shows only low salinization of the soil surface resulting from a decrease of the amount and an increase in the frequency of irrigation (the flow was about 0.15 $\mathrm{L} / \mathrm{s} / \mathrm{ha}$ at the end of the 1980s for a normal flow of less $0.35 \mathrm{~L} / \mathrm{s} / \mathrm{ha}$ ). Towards the end of the $1980 \mathrm{~s}$, many old artesian wells were depleted and several new boreholes were dug.

The development of the salinity is determined by a fast and a slow component. The slow component is a result of salinization/leaching cycles caused by irrigation. It is similar to the natural development of the soil: the usually uncultivated calcareous gypsum soils with a crust are non-saline, the saline soils affected by waterlogging are located close to the sebkhas and Chotts. This is the case of in oasis of Gafsa-South West and Guettar [3]. The second, fast component is caused by torrential rains. On 21 January 1990, e.g., more than $253 \mathrm{~mm}$ rain within a few hours induced a significant leaching of salts and a homogenization of the soil salinity, filled Chotts and Sebkhas and inundated some parcels.

In this oasis, there are three spatial scales of soil salinity: the values on the parcel and the farm are both influenced by water and soil management; the whole oasis is more influenced by topography [3]. The distribution of salts can thus be explained by four factors: topography, the land use, the size of the parcel and finally the soil type. The salinization of the soils of the oasis is in equilibrium with irrigation practices.

\subsubsection{The Continental Oasis of Tozeur and Kebili}

Since 1988, all natural springs were depleted except for some mountain oasis (Tamerza) and were replaced by drilled wells. Currently these oases are irrigated with groundwater pumped from the deep aquifer. The oases of the Jerid and Kebili differ type, crops, surrounding landscape and the existence of illegal areas. They usually develop as a crown from a traditional oasis. The oasis of the Jerid and especially those of the Nefzaoua are known by their group. They can be assimilated to a few large perimeters. Their drainage systems are very complex and interconnected inducing problems of underground water flow.

The Nefzaoua and the Jerid oases have special properties. Many of them have areas located downstream sometimes very important compared to the "mothers" oases. These problems of these areas are mainly related to irrigation and the increasing extraction of groundwater from wells. These groundwater layers communicate with drainage waters and have therefore higher salinity. The hydrology of these areas is not well known and requires further studies.

The amount of gypsum crusts is directly linked to the duration of shallow water table. The abundance of water resources and the shallow depth of the water table have caused a mismanagement of these resources by excessive and uncontrolled use. Water saving operations helped to reduce losses and mitigate salinization and waterlogging problems.

\subsection{Degradation of Aquifers Quality}

The overexploitation of deep aquifers induces a movement for more saline waters to these aquifers 
from soil surface to the subsoil. Several oases currently use additional groundwater increase the amounts of salts in the soils. With the decrease of the water level of the deep aquifer, the water of the shallow groundwater can infiltrate and contributes to the salinization of the lower aquifers. The proliferation of the wells resulted in a lower piezometric level. Generally, a chemical deterioration has not been observed, however due to the proximity of the Chotts and the Sebkhas and the decrease of the groundwater level would inevitably result in the intrusion of more saline water. The Jeffara aquifer shows a decrease of piezometric level resulting from the increase of the exploitation and the succession of several drought years. The degradation of water quality is observed in some regions (Mareth). It is attributed to the overexploitation and the use of the lower aquifers with a higher content of minerals.

\section{Management Salinity and Waterlogging}

Several techniques are used to manage salinity and waterlogging in the oases. Generally, a combination of agricultural techniques and management operations are used which depend on climatic condition, availability of water, suitable crops and financial resources. The most frequently used options for the management of salinity and waterlogging are introduced below.

\subsection{Irrigation}

The exploitation of groundwater has an unequal spatial distribution caused by different population density and economic activity. Several sources were used for irrigation before the creation of drilling at the beginning of the last century. The exploitation of the resources in deep aquifer in agriculture is higher in Kebili (Table 2).

In the Jerid, the sources were completely depleted in 1988. Traditionally in the oasis of Tozeur, the Wadi (small river) collected the waters of the sources and divided it at the level of the dispatcher in branches related to the size of the weirs that feed Seguias (small canal) which bring water, after further subdivisions, to the parcels. This distribution of water dates back to the fifteenth century and is known as the method of $I b n$ Chabbat. The sharing of the water of a Wadi is proportional to the flow in the Seguia. If the volume from the sources, increases or diminishes, the amount allocated in the Seguias remains in the same proportions.

In the old oases, irrigation systems made in the early 1950s did not allow an efficient use of water. The loss of water from the source to the parcel was estimated as $30-50 \%$. The organization of irrigation became difficult and did not satisfy at all the needs of the farmers. The renovation of the oases has been initiated in the Management Plan of the use of the waters of South (Plan Directeur des Eaux du Sud: PDES) which doubled mobilized water resources and modernized water infrastructure. The distribution of water has been improved by the development of the water frequency by updating the parcel plans and supporting the use of water by farmers associations. In 1995, the dose applied gravity in the oases of Draa South near Tozeur town and adjacent to the Chott Jerid covering 200 ha was about $180 \mathrm{~m}^{3} /$ ha for a projected $480 \mathrm{~m}^{3} / \mathrm{ha}$. The farmer was forced to irrigate the half of its field bringing the effective frequency to

Table 2 Exploitation of water resources of deep aquifer in agriculture-year 2000.

(in millions cubic meter; $\mathrm{Mm}^{3}$ )

\begin{tabular}{lllc}
\hline Gouvernorate & Total exploitation $\left(\mathrm{Mm}^{3}\right)$ & & Exploitation for areas irrigated by more $3 \mathrm{~g} / \mathrm{L}$ \\
\hline & & $\mathrm{Mm}^{3}$ & Amount (\%) \\
Gafsa & 39.7 & 8.0 & 20 \\
Tozeur & 136.2 & 52.6 & 39 \\
Kebili & 346.9 & 31.3 & 9 \\
Gabes & 90.7 & 34.0 & 38 \\
\hline
\end{tabular}


$10 \mathrm{~d}$. The modernization of the system and the installation of closed tubes realization of water buried canals to the pillar of irrigation, helped limit losses.

In the oases of southern Tunisia, surface irrigation is the most widespread method. Due to the very permeable soils, the water losses in the frequently more than $200 \mathrm{~m}$ long Seguia were higher than 30\%. The situation has improved with the project of Development of irrigated perimeters of the South (APIOS) where several kilometres of open Seguias have been replaced by Seguias made of concrete or PVC. The traditional gravity irrigation method remained unchanged, because sprinkler irrigation is unsuitable for the Oases system and microirrigation is still rare (Table 3 ).

The most frequently planted crop is still the palm tree, followed by olive trees. In the oases of Gabes pomegranates, forage crops and vegetables are widespread. In Gabes the commercial crops henna (cosmetic plant) and tobacco are also grown (Table 4).

\subsection{Drainage}

The drainage is an old practice in the oases situated along chotts or the sea. The drainage by open ditches is the most widespread technique [5]. The network consists generally of large canals of approximately 2.5 $\mathrm{m}$ width in "U", "V" or "Y" form, oriented in the direction of the slope. The secondary collectors with an average depth of $1.5 \mathrm{~m}$ and a distance from 100 to $200 \mathrm{~m}$ are heading towards a depression or a Chott. In the old oases, drainage with open ditches or pipes was difficult due to the complex topography. The use of pipes is a new technique and now more widespread. In the new oases, drainage was frequently not planned despite the presence of gypsum crust in a depth of a few meters. The increase of the water table and the waterlogging has led to the development of ditches. Currently, most oases have drainage networks with open ditches. Unfortunately, some of these ditches suffer from bad maintenance, insufficient slopes for an effective drainage and are buried by sand. The consequence is upwelling of water and the salinization of soils and a subsequent decrease crop yields. In the recent or reconstructed oases pipe drainage system is more frequently used. The total length of the drainage network amounts to several hundred kilometers.

\subsection{Sandy Amendment}

The addition of a sand layer is a fairly common practice employed by farmers in the oases of Kebili and Tozeur affected by shallow saline water table. Periodically, a layer of dune sand is applied with a thickness between 20 and $100 \mathrm{~cm}$. This sandy amendment increases the thickness of the surface

Table 3 Irrigation methods used in the oases.

\begin{tabular}{|c|c|c|c|c|c|c|c|}
\hline \multirow{2}{*}{ Governorate } & \multicolumn{2}{|c|}{ Surface } & \multicolumn{2}{|c|}{ Sprinkler } & \multicolumn{2}{|c|}{ Localized } & \multirow{2}{*}{$\frac{\text { Total }}{\text { (ha) }}$} \\
\hline & (ha) & $\%$ & (ha) & $\%$ & (ha) & $\%$ & \\
\hline Gafsa & 1618 & 76.2 & 110 & 5.2 & 395 & 18.6 & 2123 \\
\hline Gabes & 6251 & 94.5 & 200 & 3 & 162 & 2.5 & 6613 \\
\hline Tozeur & 5184 & 99.8 & 0 & 0 & 8 & 0.2 & 5192 \\
\hline Kebili & 8530 & 99.9 & 0 & 0 & 6 & 0.1 & 8536 \\
\hline
\end{tabular}

Table 4 The exploitation of the oases-2000.

\begin{tabular}{lllllll}
\hline Governorate & Vegetables & Cereals & Forages & Industrial crops & Intercrops & Fruit trees \\
\hline Gafsa & 991 & 59 & 335 & 6 & 0 & 542 \\
Tozeur & 526 & 0 & 319 & 0 & 0 & 4897 \\
Kebili & 898 & 0 & 2560 & 0 & 3450 & 8527 \\
Gabes & 4920 & 10 & 1985 & 305 & 3237 & 3545 \\
\hline
\end{tabular}


layer and reduces the capillary rise of salts by the creation of a lithologic discontinuity resulting in a decrease of salinity and soil water saturation. Unfortunately there are no scientific studies about the efficiency of this traditional treatment.

\subsection{Reuse of Drainage Waters}

The development of oases ecosystem is often limited by rare water resources. These oases are often situated in the lower parts of the landscape around the Chotts. The missing drainage in these areas often resulted in an increase of the water table and soil salinization. Recent developments stipulated by the national project to save irrigation water have already reduced water loss significantly. In this context of water scarcity, the enhancement of water drainage was undertaken in a voluntary manner by some farmers a decade in some oasis.

The outlets of the oases often consist of endoreic depressions called "Sebkha" or "Chott" which receive large quantities of salts. It is possible that a part of this amount is transferred to the groundwater and the deep aquifers. In addition, some continental oases do not have the possibility to evacuate drainage water to the Chotts. There, waters are released near the oasis in new salt lakes [6]. Millions of cubic meters are thus evacuated each year to the lower compartments of the landscape. In 1993, the average flow of the drainage waters from the Néfzaoua oases (including the peninsula of Kebili oases) amounts to 12 to $3 \mathrm{~m}^{3} / \mathrm{s}$ (95 millions $\mathrm{m}^{3} /$ year). This has caused an excessive rise of the water table and the creation of new lakes in several oases in the region.

The disposal of drainage water poses a serious problem, especially in the long term [6]. In the short term, the drainage waters with very high salt content cause increasing watertable and the soil salinization. The reuse of drainage water is thus necessary and currently realized in several ways.

In some areas, drainage water is reused illegally for irrigation. The reused waters are a variable mixture of drainage water and the water of the water table.

Experiments with a mixture of drainage water from upstream with irrigation waters of oasis of downstream have been considered and carried out at small scales. According to current standards, the salt content of the drainage water varies between 8 and 12 $\mathrm{dS} / \mathrm{m}$ and does not allow to practice this reuse on a large scale.

The open drains in several oases joined the Seguias downstream do not allow to control quantity and quality of the irrigation water.

Finally, agroforestry of halophytes (Tamarix and Atriplex) is tested at the oasis located downstream of the outlets to prevent the emergence of "Lakes" of saline water with harmful influences on the environment. These techniques are an interesting form of water reuse because they combine environmental effectiveness (stabilization of the soil by the vegetation, reduction of the impact of salt lakes) and economic efficiency (use of halophytes as firewood or fodder). This type of recovery is tested since two decades in the oasis of Chemsa.

All these "anarchic" illicit uses have been applied in several oases with varying degrees of success and they have been monitored to assess the quantities and the salinity of drainage water and the impacts on soils crops. In recent years, the oases of Kébili have controlled the flow and salinity of the water of the outlet of the main canal. In 2002, the total flow was about $464 \mathrm{~L} / \mathrm{s}$ with $50 \%$ of the values above $5 \mathrm{~g}$ salts/L. The low values accure mostly in winter and are characterized by high flows and low salinities and while the typical summer pattern is low flow and high salinity. A study was carried out in the oasis of Chemsa on illicit and a forest area irrigated since 1993 with drainage water. The characterization of water drainage at the level of several sites showed a spatio-temporal variability of flow and quality. Drainage water is recovered in three forms, within the oasis by a shallow well and outside the oasis by a forest domain and an illicit area. 
Finally, the reuse of drainage water requires an integrated approach, new and flexible skills to link irrigation, crop and soil management in the context of economic feasibility and environmental impact. Thus, using saline drainage water requires many changes of standard management practices like the selection of appropriate crops, the improvement of the management of water and soil, a more suitable crop rotation and in some cases, the use of advanced irrigation technology.

\subsection{The Use of Geothermal Water}

The intensive use of geothermal water for irrigation in greenhouses began in Tunisia after the deep drilling in the water of the Intercalary Continental in the 1980ies. The project was started to safeguard of the existing oases and it has identified a significant geothermal potential [7]. Since its introduction, the use of geothermal energy has changed dramatically. Cultivated areas have multiplied over the years from more than 100 ha. More than half of this area is grown in continuous and the rest in later season crops and early season crops. The geothermal waters have an electrical conductivity (ECw) between 3.2 and 4. 5 $\mathrm{dS} / \mathrm{m}$, total dissolved salt (TDS) between 2.3 and 4.0 $\mathrm{g} / \mathrm{L}$ and SAR between 5 and 10 with high levels of $\mathrm{Ca}$, $\mathrm{Mg}$, Na and $\mathrm{Cl}$. Due to the high salinity of the waters and the intensive farming, salinity problems appeared very quickly in the greenhouses. To reduce salinization, several methods were used including the leaching of salts from the root zone with drainage. In the region of Gabes a sand layer was added to the soil. This crop practice partially solved the problem of salinity induced by the geothermal waters. However, its technico-economic feasibility is not completely proven [8].

\subsection{The Use of Treated Wastewater}

The use of treated domestic wastewater is new in the oases areas. About 317 ha have been recently developed in Aguila (117 ha, Gafsa) and Edissa (200 ha, Gabes) with fodder plants and fruit trees as crops. In Tozeur, treated wastewaters are used for a golf area.

\section{Conclusions}

The Tunisian southern oases are complex ecosystems which are threatened by recent developments. Their survival depends first on the efficient use of water because most of the water used is few-renewable fossil water. Good management of these saline waters requires leaching of salts, but the leachate threatens the lower parts of the landscape and contaminates the groundwater. Drainage is a prerequisite for irrigation in the Saharian area where gypsum crusts are common. Otherwise, waterlogging and subsequent salinization becomes inevitable. In the Tunisian South, salinization of soils is in the first place a drainage problem. The permeable sandy-gypsum soil facilitates fast and easy leaching and the low capillary rise of salts. However, the conditions in practice are more complex and at the plot scale the conditions vary widely. Therefore, the study of the salinization of soils must include agroclimatic, hydropedologic and human terms. The behavior of the farmer is fundamental in the management of soil and agricultural strategies, but he does not always use the best irrigation methods. It is important to protect the environment of the oasis from soil salinization and degradation. The problem of the control of water and salts may be solved if we have a complete control of the water and salt balance. At the actual level of knowledge further studies are needed.

\section{Acknowledgments}

The authors would like to thank Dr. Georg Hoermann, Dep. Of Hydrology and Water Res. Manag., Inst. For Natural Res. Conserv., Kiel Univ., Germany for his help to improve the text.

\section{References}

[1] Hachicha, M., and Abdelgawed, G. 2012. "Aspects of Salt-affected Soils in Some Arab Countries." $A W W$ Magazine 36 (9): 35-39.

[2] Ben Aissa, I., Bouarfa, S., Vincent, B., Chaumont, C., 
and Perrier, A. 2013. "Drainage Performance Assessment in a Modernized Oasis System." CIID Irrig. and Drain. J. 62: 221-228. doi:10.1002/ird.1710.

[3] Job, J. O. 1992. "Les Sols Salés de L'oasis D'El Guettar." Thèse Doc., Univ., Montpellier II.

[4] Mtimet, A., and Hachicha, M. 1995. "Hydromorphie et Salinisation Dans Les Oasis Tunisiennes." Revue Sécheresse 6 (4): 319-324.

[5] Hachicha, M. 2002. "Evaluation of the State and Need in Capacity Building for Drainage in Tunisia." In Capacity Builiding for Drainage in North Africa. IPTRID/FAO.
[6] Hachicha, M., Zimmer, D., Bahri, A., and Bouarfa, S. 1998. Drainage Water Disposal in Tunisian Continental Oasis: Problems, Concerns and Solutions. Indonesia: Bali ICID Workshop on the use of saline and brackish water for irrigation.

[7] Ben Mahmoud, M. 2003. "Geothermal Resources Development in Agriculture in Kébili Region, Southern Tunisia." Geothermics 32: 505-511.

[8] El Khaldi, R., Mougou, A., and Hachicha, M. 2006. "Saline Geothermic Water in the South of Tunisia: Resources, Use in Greenhouses and the Problem of Salinity." Arab Water World Magazine 30 (2): 56-57. 